\title{
ANALISIS TOTAL QUALITY CONTROL SEBAGAI UPAYA MEMINIMALISASI RESIKO KERUSAKAN PRODUK PADA CV ANUGRAH JAYA LAMONGAN
}

\author{
Evi Yulia \\ Fakultas Ekonomi, Universitas Islam Lamongan
}

\begin{abstract}
ABSTRAK
Tujuan penelitian ini adalah untuk mengetahui pendekatan Total quality control sebagai upaya meminimalisasi resiko kerusakan produk dan factor factor yang menyebabkan kegagalan kulitas produk pada CV Anugrah Jaya Lamongan. Metode yang digunakan dalam penelitian ini adalah 7 analisis statitik yaitu menggunakan peta kendali P, Diagram control cacat 100 persen, diagram sebab akibat dan metode kaizen.Hasil penelitian ini menunjukkan bahwa dengan menggunakan peta kendali $p$ rata-rata kerusakan produk CL sebesar 0,019, batas kendali produk atau UCL sebesar 0,025.dan LCL sebesar 0,013 dari hasil perhitungan peta kendali P menunjukkan total quality control atau pengendalian kualitas produk dikatakan baik, sedangkan menggunakan diagrm control cacat 100 persen menunjukkan CL sebesar 1,910 persen, UCL 2,53 persen, LCL sebesar 1,29 persen. Berdasarkan hasil perhitungan diagram control cacat 100 persen menunjukkan hasil Total quality control atau pengendalian kualitas produk dikatan baik. Berdasarkan hasil analisa menggunakan diagram sebab akibat faktor-faktor yang menyebabkan kegagalan kualitas produk adalah manusia, mesin, metode dan lingkungan dianalisis menggunakan metode kaizen menunjukkan bahwa pengawasan harus terus dilakukan untuk menjaga kualitas produk dengan mengawasi kinerja pegawai, memberikan intruksi yang jelas kepada pegawai sehingga metode dan factor manusia dapat terlaksa dengan baik, untuk factor lingkungan yaitu mengawasi gudang dan membersihkan gudang setiap waktu agar kotoran dan debu tidak bercampur dengan bahan baku sedangkan factor mesin yaitu melakukan pengawasan dan perawatan mesin agar mesin tetap optimal.
\end{abstract}

Kata kunci: Pendekatan total quality control, factor penyebab kegagalan produk, produk cacat

\section{PENDAHULUAN}

Pada hakekatnya suatu perusahaan

didirikan untuk mencapai keuntungan yang optimal. Dengan keuntungan yang maksimal maka suatu perusahaan dapat terus menjalankan bisnis dan terus berproduksi untuk memenuhi kebutuhan dan keinginan konsumen. Dengan keuntungan yang diperolehnya itu perusahaan akan dapat mempertahankan usahanya, sehingga kelangsungan hidup perusahaan akan terjamin. Pelaksanaan pengawasan dalam perusahaan merupakan fungsi yang terakhir dalam akifitas perusahaan. Dengan terus melakukan pengawasan maka segala 
sesuatu yang dapat merugikan perusahaan dapat diminimalisasi.

Peran mutu sebagai sumber keunggulan kompetitif telah dibuktikan oleh sejarah. Setelah perang dunia telah berakhir, para ahli secara intensif mempelajari manajemen mutu dengan mengadopsi konsep mutu para ahli dari Amerika. Penerapan pengendalian mutu terpadu ini merupakan salah satu faktor yang mendorong terjadinya revolusi mutu dalam berkompetensi dengan produk - produk lainnya di pasar internasional

Total Quality Control atau pengendalian mutu terpadu dilakukan dengan jalan melaksanakan kegiatan pengawasan baik selama proses produksi atau pengawasan atas hasil barang produksi

Pengendalian mutu (Quality Control) merupakan aktifitas kelompok dan tidak bisa dilaksanakan secara individu. Program mutu akan berhasil jika semua pihak, mulai pimpinan perusahaan sampai buruh dan sales bekerjasama.

Pengendalian kualitas mulai banyak diterapkan oleh berbagai perusahaan di Indonesia. Dengan mengimplementasikan pengendalian kualitas, perusahaan akan mendapatkan beberapa keuntungan, diantaranya adalah dimana perusahaan dapat melakukan peningkatan kualitas produk, meningkatkan produktifitas dengan mengurangi produk yang rusak, mengantisipasi ketidaksesuaian dalam proses produksi sehingga produk yang dihasilkan tetap sesuai dengan standar dan spesifikasi yang telah ditentukan perusahaan, menghilangkan biaya yang tidak perlu pada saat proses produksi, serta memperoleh kenaikan profit.

\section{Tujuan Quality Control berarti} memenuhi kepuasan pelanggan terhadap produk dan pelayanan. Membuat kesinambungan antara kualitas dan biaya. Kualitas dapat dicapai secara ekonomis dan efisien hanya bila tiap proses dapat memberi jaminan kualitas pada tiap proses - proses berikutnya.

\section{Pendekatan Total Quality Control} menciptakan rasa percaya diri pada karyawan dan kemungkinan perusahaan menemukan kegagalan secara dini sebelum menjadi suatu bencana, setiap karyawan dibiasakan berbicara kepada karyawan yang lain dengan penuh kejujuran, terbuka dan saling membantu.

Dalam hal ini menekan tingkat kerusakan produk perlu dilakukan suatu pengendalian secara kontinyu terhadap proses produksi. Disamping itu, secara 
teratur pula dilaksanakan suatu audit untuk menilai tingkat efisiensi dan efektifitas dalam proses produksi, sebagai hasilnya konsumen dapat menerima produk yang berkualitas baik serta didukung oleh harga yang relatif murah karena peningkatan efisiensi dan efektifitas yang terjadi sehingga diharapkan bisa menghasilkan kepuasan konsumen terhadap hasil produksi yang akhirnya dapat meningkatkan laba perusahaan.

Total Quality Control diharapkan bermanfaat dalam mengidentifikasi penyebab kerusakan pada hasil produksi yang menyebabkan rendahnya kualitas produk yang dihasilkan. Sehingga diketahui sumber - sumber penyebab kerusakan produk tersebut, maupun cara pemecahannya suapaya dimasa yang akan datang dapat meminimalisasi jumlah kerusakan yang terjadi.

Kualitas pada produk merupakan focus saat ini yang sedang dijalani oleh setiap perusahaan, melihat dari manajemen operasional kualitas produk merupakan salah satu kebijaksanaan penting dalam meningkatkan daya saing produk untuk memuaskan kebutuhan dan keinginan konsumen paling tidak kualitas produk setara atau lebih bagus dari kualitas produk pesaing
Biaya kulitas adalah biaya yang terjadi atau mungkin akan terjadi karena kulitas yang buruk. Pandangan kulitas meliputi kualitas yang makin tinggi, biaya peningkatan kualitas lebih rendah dari pada penghematan dan biaya kualitas merupakan biaya yang besarnya melebihi biaya yang terjadi bila produk atau jasa yang dihasilkan secara benar sejak awal.

Dengan adanya peningkatan kualitas produk maka akan diikuti dengan peningkatan biaya, jika kualitas produik tinggi maka biaya juga akan ikut tinggi pula dan sebaliknya.

CV Anugrah Jaya adalah salah satu perusahaan yang menjual aneka macam produk makanan seperti kue dan roti. Dalam menjalankan bisnisnya perusahaan telah menerapkan manajemen mutu yang baik dan sesuai dengan standart mutu yang berlaku untuk menjamin kualitas produk

Berbagai program dilakukan perusahaan untuk menjamin kualitas produk sehingga dapatv menghasilkan produk yang baik dan sesuai dengan standart yang ditetapkan, akan tetapi masih saja terdapat produk yang kualitasnya buruk, seperti kemasan rusak, olahan bahan baku yang tidak sempurnadan lain sebagainya.hal 
tersebut dapat menjadi suatu kerugian bagi perusahaan karena dapat mengakibatkan pemborosan dalam produksi.

Berdasarkan latar belakang di atas maka penulis tertarik mengambil judul penelitian " Analisis Total Quality Control Sebagai Upaya Meminimalisasi Resiko Keruskan Produk Pada Cv Anugrah Jaya Lamongan"

Rumusan masalah dalam penelitian ini adalah (1) bagaimana pendekatam Total Quality Control (TQC) sebagai upaya meminimalisasi resiko kerusakan produk pada $\mathrm{CV}$ Anugrah Jaya Lamongan. (2) faktor faktor apa saja yang menyebabkan kegagalan kualitas produk pada $\mathrm{CV}$ Anugrah Jaya Lamongan

Tujuan dari penelitian ini adalah Untuk mengetahui pendekatan Total Quality Control (TQC) sebagai upaya meminimalisasi resiko kerusakan produk pada CV Anugrah Jaya Lamongan. (2) Untuk mengetahui faktor - faktor apa saja yang menyebabkan kegagalan kualitas produk pada CV Anugrah Jaya Lamongan.

Manfaat dari penelitian ini adalah Secara Teoritis (1)Dapat menambah ilmu pengetahuan khususnya ilmu manajemen. (2) Dapat memberikan kontribusi mengenai pentingnya manajemen produksi. (3)Dapat digunakan sebagai bahan pertimbangan dalam pengambilan keputusan untuk tercapainya tujuan perusahaan.

Manfaat Secara Praktis. (1)Bagi Penulis, Dengan melakukan kajian ilmiyah maka wawasan peneliti akan lebih luas dan hal ini berguna bila kelak didalam masyarakat untuk waktu yang akan datang.(2) Bagi Perusahaan (a)Memberikan gambaran yang lebih kongkrit mengenai aplikasi konsep operasional dalam situasi yang sebenarnya bagi perusahaan. (b) Memberikan informasi yang didapat dari hasil penelitian sehingga bermanfaat dan sebagai bahan pertimbangan bagi pimpinan perusahaan dalam menentukan langkah - langkah yang harus diambil untuk mengatasi jumlah kerusakan hasil produksi pada perusahaan. (c) Dapat menambah pengetahuan yang lebih dalam mengenai Total Quality Control dalam keadaan nyata didalam perusahaan guna pengembangan dimasa yang akan datang. (2)Bagi Universitas, Diharapkan dapat berguna untuk menambah daftar pustaka di perpustakaan dan sebagai studi perbandingan bagi mahasiswa yang akan datang, khususnya mengenai manajemen 
operasional dan produksi.(3)Bagi Pembaca (a) Hasil penelitian diharapkan bisa dijadikan dasar pengetahuan bagi pembaca tentang manajemen operasional dan produksi dalam mengatasi jumlah kerusakan hasil produksi pada perusahaan. (b)Sebagai dasar untuk mengetahui lebih lanjut tentang sistem Total Quality Control.

\section{TINJAUAN PUSTAKA}

\subsection{Total Quality Control}

Menurut Malayu (2016 : 219) Untuk mengenal Total Quality Control kita perlu mengetahui sejarah perkembangan TQC. Sejarah total quality control dari tahun 1920 sampai tahun 1978 terus saja berkembang karena penggunaan TQC memberikan banyak manfaat kepada perusahaan karena dapat meminimalisasi jumlah kerusakan produk. Dibawah ini adalah sejarah perkembangan dari TQC adalah (a )Tahun 1920 sampai tahun 1940 Pengendalian mutu (quality control) mulai dilakukan di Amerika Serikat terbatas pada produk pabrik, kemudian mulai tahun 1940 dilakukan dengan metode statistik. (b)Tahun 1940 sampai tahun 1950 Penerapan pengendalian mutu dengan statistik dan mulai diadakan penelitian secara kelompok untuk mengendalikan mutu dimaksud. (c)Tahun 1950 sampai tahun 1955 Pengembangan pengendalian mutu dengan menekankan sebagai bagian integral dari pengendalian manajemen. (d) Tahun 1955 sampai tahun 1960 Manajemen yang menekankan pada hasil/MBO (management by objective $=$ MBS) dikembangkan untuk menggarisbawahi perencanaan strategis (strategic planning) dan pengembangan manajemen. (e) Tahun 1960 sampai tahun 1965 Mulai diperkenalkan Quality Control Circles $(\mathrm{QCC}=\mathrm{GKM}=$ gugus kendali mutu) sebagai penggalakan pemeriksaan dengan pengendalian mutu, agar seluruh karyawan tertinggi sampai dengan terbawah mempelajari metode statistik dan berpartisipasi aktif dalam pengendalian mutu. (f)Tahun 1965 sampai tahun 1978 QCC gaya Jepang lebih dikenal dengan nama TQC yang menekankan PDCA (Plan-Do-CheckAction) pada seluruh tingkat organisasi oleh semua orang.

Menurut Agus Ahyari (dalam Hadi 2016 : 46) Quality atau kualitas merupakan suatu aktivitas (manajemen perusahaan) untuk menjaga dan mengarahkan agar kualitas produk dan jasa perusahaan dapat dipertahankan sebagaimana yang telah direncanakan. 
Menurut Ariani (dalam Hadi 2016 : 46) Quality atau kualitas yaitu dalam menentukan baik tidaknya kualitas suatu produk tidak hanya dikaitkan dengan kegunaan dari produk tersebut saja. Ada dua hal yang menjadi pertimbangan dalam menentukan kualitas yaitu sifat sifat fisik dan sifat - sifat kimia yaitu (a) Sifat - sifat fisik yaitu berhubungan dengan kekuatan atau daya tahan dari suatu benda.(b) Sifat - sifat kimia yaitu berhubungan dengan reaksi kimia atau persenyawaan kimia yang timbul akibat dari terjadinya hubungan antara benda yang satu dengan benda yang lain.

Dua hal ini sangat penting kaitannya dengan perusahaan karena dapat menjadikan penilaian bagi perusahaan dan kususnya bagi konsumen terhadap kualitas barang yang didasarkan atas tujuan kegunaan atau pemakaian dari barang itu sendiri.

Menurut Ibrahim (dalam Hadi 2016 : 45) Control atau pengawasan adalah jaminan bahwa hasil yang dicapai sesuai dengan apa yang diharapkan. Menurut Sofyan Assauri (dalam Hadi 2016 : 45) Control atau pengawasan adalah kegiatan pemeriksaan atau pengendalian atas kegiatan yang telah dan sedang dilakukan, agar kegiatan tersebut dapat sesuai dengan apa yang diharapkan atau direncanakan.

Menurut Sofyan Assauri (dalam Malayu 2016 : 222), bahwa pengendalian mutu terpadu adalah suatu sistem manajemen yang melibatkan semua tingkatan karyawan melalui pelaksanaan konsep quality control dan metode statistik untuk memuaskan langganan dan karyawan.

Menurut Muchdarsah Sinungan (dalam Malayu 2016 : 222) "pengendalian mutu terpadu ialah suatu sistem yang mengikut sertakan seluruh anggota baik tingkat pimpinan atau pelaksana dengan konsep dan teknik kendali mutu untuk mendapatkan kepuasan konsumen".

Menurut Suryadi Prawirasentono (dalam Malayu 2016 : 222)”, pengendalian mutu terpadu adalah kegiatan terpadu mulai dari pengendalian standart mutu bahan, sampai standart pengiriman produk akhir konsumen, agar barang atau jasa yang dihasilkan sesuai dengan spesifikasi mutu yang direncanakan".

Menurut Malayu (2016 : 222)

Total Quality Control adalah suatu sistem yang efektif untuk mengintegrasikan usaha-usaha pengembangan kualitas, pemeliharaan 
kualitas, dan perbaikan kualitas atau mutu-mutu dari berbagai kelompok dalam organisasi, sehingga meningkatkan produktivitas dan pelayanan ke tingkat yang paling ekonomis yang menimbulkan kepuasan semua langganan.

Menurut Malayu (2016 : 220) Dasar total quality control adalah mentalitas dengan mengutamakan kualitas kerja. Mentalitas adalah kesediaan bekerja sungguh-sungguh, jujur dan bertanggung jawab melaksanakan pekerjannya.

Menurut Malayu (2016 : 221) Mentalitas dasar Total Quality control mencakup (a) Kerjasama dan Partisipasi Total, Agar karyawan mengetahui caracara dalam membangun sikap mental dasar di lingkungan pekerjaan masingmasing, tujuannya adalah

Berorientasi kepada tanggung jawab kelompok, (2)Bersedia membuat lebih/berpartisipasi dalam bidang yang berhubungan.(3)Menciptakan kesadaran kelompok. (4) Dapat saling menghargai antara golongan/tingkatan.(b) Berorientasi Kepada Mutu atau kualitas, Pada dasarnya kualitas mengacu kepada beberapa hal diantaranya adalah disesuaikan dengan permintaan, sistemnya adalah pencegahan sejak awal dikerjakan dengan benar, standarnya adalah tidak ada cacat/harus tidak ada kesalahan, ukurannya adalah biaya untuk mencapai kualitas .

\section{Dalam Total Quality Control} kesadaran karyawan mengenai kualitas harus selalu ditingkatkan sehingga dapat menimbulkan sikap loyalitas pada perusahaan. Adapun prinsip - prinsip kualitas antara lain (a) Kepuasan pemakai, jadi berorientasi pada pemakai, bukan pada standar. (b) Mencakup kualitas dari semua jenis pekerjaan. (c) Merupakan tanggung jawab setiap orang sehingga sejak awal harus dilaksanakan dengan benar

Ada beberapa hal yang mencakup kualitas antara lain (a) Produk, orang dan aktivitas, (b) Biaya, (c) Pengiriman, (d) Keselamatan, (e) Moral

Ada beberapa langkah - langkah yang perlu diambil dalam rangka penetapan standar kualitas menurut Malayu (2016 : 224) adalah (a) Mempertimbangkan produk dari pesaing (b) Mempertimbangkan kegunaan terakhir atau fungsi terakhir dari produk (c) Kualitas produk harus sesuai dengan harga jual (d)dDiperlukan team yang terdiri dari departemen penjualan, departemen teknik, departemen pembelian, departemen produksi dan 
departemen pemeriksaan dalam rangka menentukan bentuk standar produk yang dihasilkan. (f) Setelah ditentukan standar produknya maka perlu standar quality dari produk tersebut perlu dipelihara, yaitu dengan cara dilakukan pengamatan produksi.

Menurut Malayu (2016 : 222) Pencapaian tujuan atas kualitas yang direncanakan oleh perusahaan dalam proses produksi perlu dituntut dengan adanya pelaksanaan Total Quality Control. Adapun tujuan pelaksanaan Total Quality Control adalah sebagai berikut (a) Pencapaian kebijaksanaan dan target perusahaan secara efisien, (b) Perbaikan hubungan manusia serta mutu barang atau jasa. (c) Peningkatan moral, prakarsa dan kerjasama karyawan. (d) Pengembangan kemampuan tenaga kerja. (e) Peningkatan produktivitas dan pofitabilitas usaha

Menurut Malayu (2016 : 223) dengan pelaksanaan Total Quality Control yang sebaik - baiknya, maka banyak manfaat yang bisa diperoleh antara lain (a) Meningkatkan kemampuan karyawan dalam melihat, mengenali permasalahan dan mencari alternatif pemecahan masalah. (b) Meningkatkan kemampuan komunikasi dan partisipasi didalam kelompok kerja. (c) Membiasakan berpikir secara analitis dengan menggunakan teknik quality control. (d) Peningkatan daya kreativitas. (e) Peningkatan kepercayaan diri. (f) Pengembangan perusahaan melalui akumulasi gagasan - gagasan perbaikan. (g)Meningkatkan daya saing barang atau jasa yang dihasilkan. (h) Memperbaiki hubungan perusahaan dengan karyawan. (i) Partisipasi semua karyawan didalam membantu terwujudnya tujuan perusahaan. (j) Konsumen akan memperoleh barang atau jasa yang berkualitas baik (k) Konsumen akan mendapatkan kepuasan atas barang atau jasa. (1) Konsumen akan memperoleh barang atau jasa yang memenuhi kesehatan dan keselamatan (m) Konsumen akan menerima barang sesuai dengan pesanannya. (n)Pemerintah akan mendapatkan pajak - pajak

Jika TQC dijalankan dengan baik oleh perusahaan maka manfaat dari TQC bisa dirasakan oleh perusahaan karena jika produk cacat berkurang maka keuntungan yang diperoleh oleh perusahaan juga meningkat karena berkurangnya jumlah produk cacat. Jika perusahaan tidak melakukan TQC maka dampak yang dirasakan juga 
berpengaruh terhadap penghasilan yang diperoleh oleh perusahaan.

Adapun akibat jika tidak melalukan Quality Control Menurut Malayu (2016 : 223) antara lain (a) Barang - barang sebagian besar akan ditolak oleh konsumen karena tidak memenuhi standar kualitas. (b)Kesulitan - kesulitan dalam proses produksi disebabkan karena barang - barang yang cacat atau rusak. (c) Keterlambatan produksi yang akan menghabiskan banyak biaya

Menurut Malayu (2016 : 225) Dalam pelaksanaan program Total Quality Control terdapat dua hal yang harus diperhatikan yaitu Dari Sisi Karyawan (a) Menciptakan suasana yang cocok. (b) Saling memberi informasi dan berkomunikasi. (c) Dijadikan program sukarela (d)Memberikan pengarahan dan latihan.(e) Bersikap terbuka dan positif. (f) Menyediakan waktu, sarana, fasilitas dan dana.

Dari Sisi Manajer (a) Mengajukan dan menjelaskan program Total Quality Control kepada pucuk pimpinan (b) Menjelaskan tujuan dan hasil yang akan dicapai (c) Mendapat dukungan dari pucuk pimpinan

Dalam melaksanakan TQC ternyata tidak semudah yang difikirkan pasti ada beberapa kendala yang akan ditemui selama melaksanakan atau menjalankan program TQC, adapun kendala dari pelaksanaan program Total Quality Control Menurut Malayu (2016 : 225) antara lain (a) Kendala dari Bawahan yaitu Adanya ketidaksetujuan, Merasa dimanfaatkan oleh pimpinan, Merasa sebagai beban tambahan, Adanya sikap mengapa saya harus menolong atau membantu perusahan, Tidak dijalankan/dilakukan ditempat kerjanya, Tidak ada waktu untuk berkelompok (circle) (b) Kendala dari Atasan yaitu Atasan tidak mendukung gagasan Total Quality Control, Sangat sibuk, Kurangnya kewenangan yang dimiliki, Belum memahami secara jelas pengertian Total Quality Control, Atasan menganut sentralisasi wewenang

Pada prinsipnya Menurut Suwarto (2013 : 23) proses produksi yang terdapat didalam suatu perusahaan dibedakan menjadi dua macam proses produksi, yaitu proses produksi yang terputus-putus (intermitten process) dan proses produksi yang terus - menerus (continous process).

Pengawasan kualitas pada kedua proses itu sama, yaitu ada penentuan standar kualitas, terdapat pemeriksaannya, tujuan daripada 
pengawasan kualitas tersebut agar pemeriksaan biayanya rendah dan menghemat. Selain kesamaan tersebut terdapat perbedaan yaitu karena yang satu berdasarkan pesanan maka setiap waktu perlu ditentukan standar untuk pesanan tertentu.

Perusahaan yang mempunyai proses produksi yang terus menerus dilakukan berdasarkan ramalan penjualan. Hal ini disebabkan karena kegiatan produksi tidak dilakukan berdasarkan pesanan, melainkan untuk memenuhi kebutuhan konsumen atau pasar dan dalam jumlah yang besar, serta berulang-ulang.

Adapun langkah-langkah perencanaan produksi yang dilakukan dalam perusahaan yang mempunyai proses produksi secara terus - menerus adalah (a) Membuat ramalan penjualan (sales forecasting). (b)Membuat masterschedule yang didasarkan atas ramalan penjualan. (c)Setelah masterschedule dibuat, selanjutnya dilakukan perencanaan yang lebih teliti

Perusahaan pabrik yang mempunyai proses produksi yang terputus - putus dilakukan berdasarkan jumlah pesanan (order) yang diterima, maka jumlah produksinya biasanya sedikit atau relatif sedikit. Perencanaan produksi yang dibuat tidak berdasarkan ramalan penjualan (sales forecasting), tetapi terutama didasarkan atas pesanan - pesanan yang masuk.

Perencanaan produksi dibuat untuk menentukan kegiatan produksi yang perlu dilakukan bagi pengerjaan setiap pesanan yang masuk. Ramalan penjualan ini membantu untuk dapat memperkirakan pesanan (order) yang akan diterima, sehingga dapat diperkirakan dan ditentukan penggunaan mesin dan peralatan yang ada agar mendekati optimum pada masa yang akan datang.

Kegiatan pengawasan Quality Control yang diharapkan dalam perusahaan pasti mempunyai tujuan yang ingin dicapai guna untuk menghadapi persaingan yang semakin hari semakin ketat terutama dalam perkembangan dunia industri. Maka penting sekali pengawasan Quality Control itu dilaksanakan dan menjadikan suatu yang tidak dapat dipisahkan dalam kegiatan proses produksi. Pengawasan Quality Control dalam perusahaan mempunyai tujuan Menurut Suwarto (2013 : 24) yaitu (a) Agar barang hasil produksi mencapai standart mutu yang telah ditetapkan, yang dimaksud adalah barang hasil produksi yang dihasilkan 
perusahaan dapat mencapai standart mutu yang telah ditetapkan perusahaan, yang sesuai dengan selera konsumen.(b)Mengusahakan biaya produksi menjadi serendah mungkin, yaitu perusahaan harus berusaha menekan biaya, dalam kegiatan proses produksi agar dapat serendah mungkin.(c) Mengusahakan produk yang dihasilkan selesai tepat waktu. Dalam kegiatan proses produksi yang dihasilkan perusahaan hendaknya dapat selesai tepat waktu sesuai dengan yang telah ditetapkan dan direncanakan sehingga apa yang menjadi tujuan perusahaan dapat tercapai.

Kegiatan pengawasan mutu yang sangat luas karena semua pengaruh terhadap mutu harus diperhatikan. Secara garis besarnya pengawasan mutu dapat dibedakan menjadi dua kelompok Menurut Suwarto (2013 : 24) yaitu (a) Pengawasan selama pengolahan, Banyak pengawasan secara mutu yang berkenaan dengan proses yang teratur contohnya atau dengan sampel dari hasil yang diambil pada jarak waktu yang sama dan diajukan pengecekan statistik untuk melihat apakah proses dimulai baik atau tidakknya.pengawasan terhadap proses atas bahan baku. Perlu di ingat bahwa dari proses harus dengan teratur. (b)
Pengawasan atas barang yang telah diselesaikan, Walaupun telah diadakan pengawasan kualitas dalam tingkattingkat proses tetapi hal ini belum dapat menjamin bahwa tidak ada hasil yang rusak atau kurang baik. Untuk menjaga agar barang-barang produksi yang rusak atau tidak keluar atau lolos dari pabrik sampai konsumen, maka diperlukan pengawasan atas barang hasil produksi.

Menurut Suwarto (2013 : 24) Pengawasan kualitas merupakan fungsi yang penting dalam perusahaan. Oleh karena itu setiap pabrik mempunyai pengawasan yang dilakukan oleh pengawas. Setiap orang atau bagian yang berhubungan dengan kegiatan produksi mempunyai tanggung jawab langsung atas pelaksanaan pekerjaan dan sesuainya barang hasil dengan spesifikasi yang telah ditentukan. Adapun tugas-tugas dari pengawasan terhadap proses produksi adalah (a) Pengawasan atas bahan-bahan rusak (b) Pengawasan atas kegiatan macammacam tingkatan produksi. (c) Pengawasan produksi akhir. (c) Penyelidikan atas barang-barang yang timbul

Menurut pendapat dari Rusli Syarif dalam Malayu (2016:224) bahwa "gugus Total Quality Control adalah 
suatu kelompok kecil dari bidang pekerjaan yang sejenis dalam organisasi yang mengadakan pekerjaan secara suka rela diluar jam kerja tertentu". Sedangkan menurut pendapat Kouru Ishikawa dalam Malayu (2016 : 224), bahwa "gugus Total Quality Control adalah kelompok kerja yang secara suka rela mengadakan kegiatan pengendalian mutu ditempat kerja mereka sendiri”.

Menurut Heny (2013 : 2) Dengan melalui gugus Total Quality Control ini diharapkan mutu produksi yang dihasilkan dapat ditingkatkan dan tingkat kerusakan dapat ditekan sekecil mungkin dan keadaan mutu produk dapat diketahui sejak dini. Ide dasar dilaksanakannya gugus Total Quality Control perusahaan secara menyeluruh sebagai berikut (a) Turut membantu perbaikan dan pengembangan perusahaan.(b)Menghargai kemanusiaan dan mengembangkan yang sesuai dan pantas. (c) Menggunakan kemampuan sepenuhnya dan bila perlu menggali kemampuan yang tak terbatas.

Menurut Heny (2013 : 2) Ada 9 macam pedoman kegiatan dalam gugus Total Quality Control adalah (a) Pengembangan diri, (b) Kesukarelaan, (c) Kegiatan kelompok, (d) Partisipasi karyawan, (e) Pemanfaatan teknik-teknik kendali mutu, (f) Kegiatan yang berhubungan erat dengan tempat kerja, (g) Vasilitas dan kesinambungan dalam kegiatan kendali mutu.

Pengembangan bersama (i) Kesadaran akan pentingnya kendali mutu

\subsection{Konsep Kaizen}

Menurut Mari Mulyadi dalam Heny (2013 : 1) bahwa produk rusak adalah produk yang tidak memenuhi standart mutu yang telah ditetapkan, yang secara ekonomis tidak dapat diperbaiki menjadi produk yang baik. Produk rusak berbeda dengan sisa bahan, Karena sisa bahan merupakan bahan yang mengalami kerusakan dalam proses produksi yang telah menyerap biaya bahan, biaya tenaga kerja dan biaya overhead pabrik.

Proses produksi suatu kegiatan merubah suatu produk (bahan mentah), menjadi produk setengah jadi atau produk jadi yang memiliki nilai ekonomis lebih tinggi, dalam proses produksi kemungkinan akan timbul produk cacat atau rusak sulit dihindari.

Faktor - faktor yang sangat berperan dalam memperoleh kualitas produksi yang baik, dimana yang menjadi faktor pendorong adalah sumber 
daya manusia, sumber daya alam dan sumber daya keuangan yang baik.

Produk rusak timbul karena sifat tidak normal produksi, penyebab utamanya kurang telitinya para pekerja, yang mengakibatkan kerugian pada perusahaan.

Produk rusak dibedakan menjadi 2 macam yaitu (a) Produk rusak tidak dapat dijual lagi, Perlakuannya sama seperti produk yang hilang pada akhir proses yaitu produk rusak perhitungan unit ekuivalen dan harga pokok produk rusak menambah harga pokok selesai. (b) Produk rusak dapat dijual lagi. Ada 3 macam perlakuannya antara lain (1) Hasil penjualan produk rusak dicatat sebagai pengaruh biaya produksi. (2) Kerugian produk rusak dicatat sebagai elemen biaya overhead pabrik. (3) Hasil penjualan dicatat sebagai pendapatan luar uasaha.

Menurut Fandy dalam Firman (2013 : 5) Kaizen merupakan istilah bahasa Jepang Kai berarti perubahan dan Zen berarti baik, Kaizen berarti penyempurnaan. Di samping itu, kaizen berarti penyempurnaan yang berkesinambungan yang melibatkan semua orang.

Dalam pendekatan kaizen terdapat beberapa konsep, adapun konsep kaizen meliputi beberapa hal Menurut Fandy dalam Firman (2013 : 5), yakni (1) Konsep 3 M (Muda, Mura, dan Muri), Konsep ini dibentuk untuk mengurangi banyaknya proses kerja, meningkatkan mutu, mempersingkat waktu dan mencapai efisiensi.(a) muda diartikan sebagai pengurangan pemborosan atau kesia-siaan. (b). Mura diartikan sebagai pengurangan perbedaan.(c) Muri diartikan sebagai pengurangan ketegangan.(2) Gerakan Kaizen Lima Langkah (5-S) Gerakan $5-\mathrm{S}$ memperoleh namanya dari inisial lima kata Jepang yang dimulai dengan huruf $\mathrm{S}$ : seiri, seiton, seiso, seiketsu dan shitshuke. Adapun penjelasannya antara lain adalah (a) Seiri (memisah misahkan), Seiri berarti memisah misahkan berkas - berkas atau barang barang dalam beberapa kategori. Barang - barang yang tidak sering kita gunakan sehingga dapat diletakkan di tempat yang jauh dari tempat kerja kita, dan barang - barang yang tidak pernah digunakan dapat disingkirkan atau dihapus. Dengan seiri ini kita dapat menghemat tempat dan dapat menciptakan tempat kerja yang nyaman sehingga akan meningkatkan efisiensi. (b) Seiton (penataan), Dengan seiton ini kita mengatur secara baik, perbekalan 
kantor, alat - alat, dokumen, suku cadang, buku dan lain - lainnya untuk membuat pencariannya kembali menjadi efisien dan efektif. (c) Seiso (pembersihan), Dalam istilah $5-\mathrm{S}$, berarti membuang sampah, kotoran dan benda - benda asing serta membersihkan segala sesuatu. Pembersihan merupakan salah satu bentuk dari pemeriksaan. (d)Seiketsu (pemantapan), Dalam istilah $5-\mathrm{S}$, pemantapan berarti terus menerus dan secara berulang - ulang memelihara pemeliharaan, penataan dan pembersihannya. Dengan demikian, pemantapan mencakup kebersihan pribadi dan kebersihan lingkungan.(e) Shitshuke (disiplin) Dalam istilah $5-\mathrm{S}$, ini berarti menanamkan (atau memiliki) kemampuan untuk melakukan sesuatu dengan cara yang benar. Dalam hal ini, penekanannya adalah untuk menciptakan tempat kerja dengan kebiasaan dan perilaku yang baik.

Langkah pertama dari kaizen adalah menerapkan siklus PDCA (plan, do, check action) sebagian sarana yang menjamin terlaksananya kesinambungan dari kaizen. Hal ini berguna dalam mewujudkan kebijakan untuk memelihara dan memperbaiki atau meningkatkan standar. Siklus ini merupakan konsep yang terpenting dari proses kaizen Menurut Imai (dalam Firman 2013: 9).

Langkah - langkah dalam penyusunan yaitu dengan menggunakan Konsep $5 \mathrm{~W}+1 \mathrm{H}$ yang merupakan salah satu pola pikir dalam kegiatan kaizen adalah dengan teknik bertanya dengan pertanyaan dasar $5 \mathrm{~W}+1 \mathrm{H}$ (what, who, why, where, when dan how).

Adapun indikator faktor penyebab kegagalan kualitas produk antara lain adalah (a) Man (manusia), (b)Lingkungan, (c) Machine (mesin), (d) Methode (metode).

\subsection{Kerangka Berfikir}

Kerangka berfikir dalam penelitian ini adalah

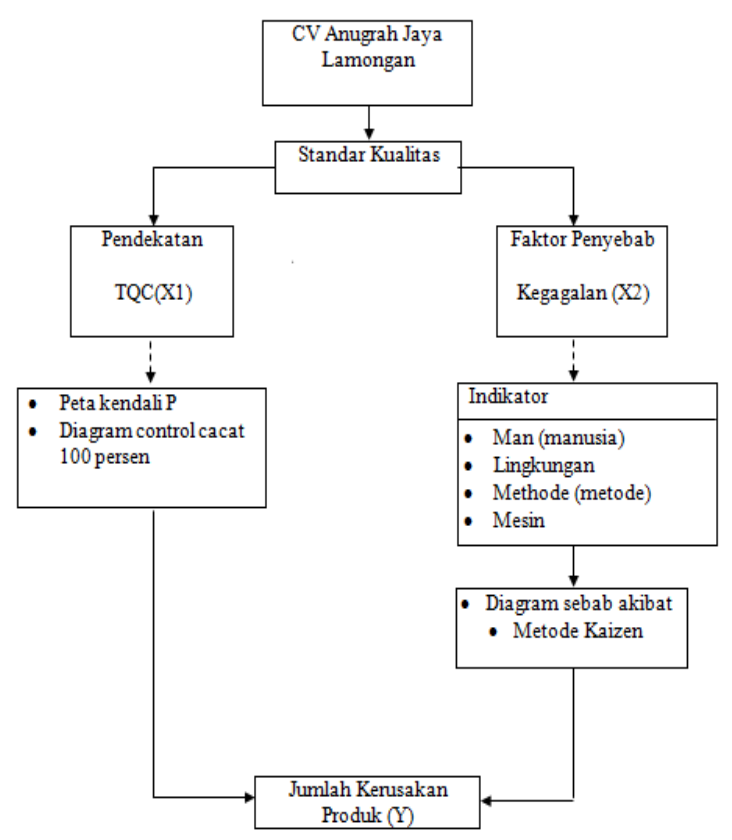

Gambar 1. Kerangka Berfikir 
Hipotesis dalam penelitian ini adalah (1) diduga bahwa Total quality control dapat meminimalisasi resiko kerusakan produk pada CV Anugrah Jaya Lamongan (2) Faktor-faktor penyebab kegagalan kualitas produk pada CV Anugrah Jaya adalah factor manusia, metode dan mesin

\section{METODOLOGI PENELITIAN}

Penelitian ini dilaksanakan pada bulan mei 2017 sampai November 2017. Penelitian ini berlangsung selama 6 bulan tujuannya adalah untuk mengetahui lebih jauh perkembangan TQC yang digunakan dalam perusahaan untuk mendapatkan hasil yang lebih valid dan akurat. Dalam penelitian ini penulis mengambil obyek penelitian di CV Anugrah Jaya Lamongan

Jenis penelitian ini merupakan penelitian deskripsi kuantitatif. Menurut Sugiyono (2014 : 279) Penelitian deskriptif kuantitatif adalah metode penelitian yang digunakan untuk meneliti kondisi obyek yang alamiah (lawannya adalah eksperimen) dimana peneliti adalah sebagai instrument kunci, pengambilan sampel sumber data, teknik pengumpulan data, dan hasil penelitian kuantitatif lebih menekankan makna dari pada generalisasi.
Penelitian ini merupakan penelitian lapangan yaitu penelitian dalam kanca kehidupan yang sebenarnya. Penelitian dilakukan dengan menggalih data yang bersumber dari lokasi penelitian yaitu yang berkenaan dengan Quality Control dalam mengurangi resiko kerusakan produk.

Populasi adalah wilayah generalisasi yang terdiri atas obyek / subyek yang mempunyai kualitas dan karakteristik tertentu yang ditetapkan oleh peneliti untuk dipelajari dan kemudian ditarik kesimpulannya (menurut Sugiyono, 2014 : 80). Populasi dalam penelitian ini adalah semua hasil produksi roti dan jumlah kerusakan produk roti bakery pada CV Anugrah Jaya Lamongan

Sampel adalah bagian dari jumlah dan karakteristik yang dimiliki oleh populasi tersebut (menurut Sugiyono 2014 : 81). Adapun sampel penelitian ini adalah semua hasil produksi roti dan jumlah kerusakan produk roti bakery pada CV Anugrah Jaya Lamongan selama 6 bulan yaitu bulan mei sampe bulan November 2017.

Teknik sampling adalah teknik pengambilan sampel. Sugiyono (2014 : 81). Teknik random sampling yaitu cara 
pengambilan anggota sampel dari populasi dilakukan secara acak tanpa memperhatikan setara yang ada dalam populasi itu. Sugiyono (2014 : 120).

Metode pengumpulan data yang digunakan dalam penelitian ini adalah dengan melakukan pengamatan langsung di perusahaan yang menjadi objek penelitian. Teknik pengumpulan data yang dilakukan adalah sebagai berikut (a) Wawancara, Menurut Sugiyono (2014 : 137) Merupakan suatu cara untuk mendapatkan data atau informasi dengan tanya jawab secara langsung pada orang yang mengetahui tentang objek yang diteliti. Dalam hal ini adalah dengan pihak manajemen/ karyawan UD. Sumber Makmur yaitu data mengenai jenis-jenis produk rusak dan penyebabnya, proses produksi serta bahan baku yang digunakan. (b) Observasi, Menurut Sugiyono (2014 : 145) Yaitu pengamatan atau peninjauan secara langsung di tempat penelitian yaitu di UD. Sumber Makmur dengan mengamati sistem atau cara kerja pegawai yang ada, mengamati proses produksi dari awal sampai akhir dan kegiatan pengendalian kualitas. (c) Dokumentasi, Menurut Sugiyono (2014 : 142) Yaitu dengan mempelajari dokumen-dokumen perusahaan yang berupa laporan kegiatan produksi, laporan jumlah produksi dan jumlah produk rusak, rencana kerja, serta dokumen kepegawaian.

Data primer adalah data yang diperoleh dari sumbernya, diamati dan dicatat untuk pertama kalinya data yang diperoleh dari sumbernya adalah semua data yang bersifat kuantitatif dan kualitatif yang langsung dikumpulkan oleh peneliti dari sumber pertama. Menurut Sugiyono (2014 : 137).

Data sekunder adalah data yang telah diolah yang diperoleh dari perusahaan buku, literatur seperti sejarah perusahaan, struktur organisasi, aktivitas perusahaan. Menurut Sugiyono (2014 : 137). Adapun data sekunder yang dibutuhkan dalam penulisan ini adalah sebagai berikut (a) Data mengenai struktur organisasi perusahaan, (b) Data mengenai jumlah hasil produksi dan realisasi penjualan, (c) Data mengenai jumlah produk yang rusak, (d) Data jumlah permintaan dan realisasi produksi. (e) Data jumlah pengawasan atau Total Quality Control

Definisi operasional variable, Pada dasarnya variabel adalah segala sesuatu yang berbentuk apa saja yang ditetapkan oleh peneliti untuk dapat dipelajari sehingga diperoleh informasi tentang hal 
tesebut, kemudian ditarik kesimpulannya (Sugiyono, 2014 : 38).

Variabel bebas adalah variabel yang mempengaruhi atau yang menjadi sebab perubahannya atau timbulnya variabel terikat / dependen (Sugiyono, 2014 : 39). Dalam kasus ini yang menjadi variabel bebas adalah Manajemen Total Quality Control (X1) dan Faktor - faktor penyebab kegagalan kualitas produk (X2), yaitu untuk mengidentifikasi faktor - faktor apa saja yang menyebabkan kegagalan kualitas produk

Variabel terikat adalah variabel yang dipengaruhi atau yang menjadi akibat, karena adanya variabel bebas (Sugiyono, 2014 : 39). Dalam kasus ini yang menjadi variabel terikat adalah Jumlah Kerusakan Produk. Jumlah Kerusakan Produk diperoleh dengan cara mengetahui berapa produk yang mengalami kerusakan dengan didasarkan pada ketentuan yang terjadi pada perusahaan

Metode analisis data yang digunakan dalam penelitian ini adalah menggunakan 7 alat statistic sebagai alat bantu untuk mengaendalikan kualitas yaitu (a ) peta kendali p yang terdiri dari (1) menghitung prosentase kerusakan, (2) Central line,(3) upper control line,
(4) lower control line, (b) Diagram control cacat 100 persen inspection, terdiri dari (1) menghitung garis pusat (2) menghitung batas kendali (3) menghitung batas kendali bawah. (c) diagram sebab-akibat (d) metode kaizen

\section{HASIL PENELITIAN DAN PEMBAHASAN}

Berdasarkan hasil perhitungan yang sudah dilakukan oleh penulis diketahui besar persentase kerusakan produk dari bulan Mei sampai November 2017 menggunakan peta kendali P adalah

Tabel 1. Prosentase Kerusakan Produk

\begin{tabular}{ll}
\hline Bulan & P misdruk \\
\hline Mei & $1,94 \%$ \\
Juni & $1,91 \%$ \\
Juli & $1,95 \%$ \\
Agustus & $1,92 \%$ \\
September & $2,09 \%$ \\
Oktober & $1,98 \%$ \\
november & $1,63 \%$
\end{tabular}

Dari data diatas total $\mathrm{P}$ misdruk selama 6 bulan terakhir adalah 13,42 persen, sedangkan berdasarkan perhitungan garis pusat yang merupakan rata-rata kerusakan produk atau besar CL sama dengan 0,019 dan besar UCL yang merupakan batas kendali dari produk sebesar 0,025 .

Jika tidak ditemukan hasil atau titik yang melebihi garis atas atau 
disebut dengan UCL atau batas toleransi misdruk secara statistic maka pengendalian kualitas dikatakan baik. Jika ditemukan hasil atau titik yang kurang dari batas LCL yaitu dibawah 0,013 berarti perusahaan telah mampu mengurangi misdruk dibawah standart yang telah ditetapkan secara statistic, jika hasil atau titik diatas 0,013 tetapi tidak melebihi batas UCL yaitu 0,025 maka pengendalian kualitas tetap dikatakan baik.

Dari hasil perhitungan diatas maka dapat dianalisis total quality control atau pengendalian kualitas produk dari $\mathrm{CV}$ Anugrah Jaya Lamongan menggunakan peta kendali $\mathrm{P}$ dikatakan baik. Hal itu dapat dilihat dari table dibawah ini

Tabel 2. CL, UCLdan LCL

\begin{tabular}{llcll}
\hline Bulan & P misdruk & CL & UCL & LCL \\
\hline Mei & $1,94 \%$ & 0,019 & 0,025 & 0,013 \\
Juni & $1,91 \%$ & 0,019 & 0,025 & 0,013 \\
Juli & $1,95 \%$ & 0,019 & 0,025 & 0,013 \\
Agustus & $1,92 \%$ & 0,019 & 0,025 & 0,013 \\
September & $2,09 \%$ & 0,019 & 0,025 & 0,013 \\
Oktober & $1,98 \%$ & 0,019 & 0,025 & 0,013 \\
november & $1,63 \%$ & 0,019 & 0,025 & 0,013
\end{tabular}

Pada bulan mei 2017 besar persentase kerusakan produk adalah 1,94 persen atau 0,019 berada di bawah batas toleransi misdruk secara statistic yaitu kurang dari 0,025 maka pengendalian kualitas CV Anugrah Jaya dikatakan baik
Pada bulan Juni 2017 besar persentase kerusakan produk adalah 1,91 persen atau 0,019 berada di bawah batas toleransi misdruk secara statistic yaitu kurang dari 0,025 maka pengendalian kualitas CV Anugrah Jaya dikatakan baik

Pada bulan Juli 2017 besar persentase kerusakan produk adalah 1,95 persen atau 0,019 berada di bawah batas toleransi misdruk secara statistic yaitu kurang dari 0,025 maka pengendalian kualitas CV Anugrah Jaya dikatakan baik

Pada bulan Agustus 2017 besar persentase kerusakan produk adalah 1,92 persen atau 0,019 berada di bawah batas toleransi misdruk secara statistic yaitu kurang dari 0,025 maka pengendalian kualitas CV Anugrah Jaya dikatakan baik

Pada bulan September 2017 besar persentase kerusakan produk adalah 2,09 persen atau 0,021 berada di bawah batas toleransi misdruk secara statistic yaitu kurang dari 0,025 maka pengendalian kualitas CV Anugrah Jaya dikatakan baik

Pada bulan Oktober 2017 besar persentase kerusakan produk adalah 1,98 persen atau 0,019 berada di bawah batas toleransi misdruk secara statistic yaitu 
kurang dari 0,025 maka pengendalian kualitas CV Anugrah Jaya dikatakan baik

Pada bulan November 2017 besar persentase kerusakan produk adalah 1,63 persen atau 0,016 berada di bawah batas toleransi misdruk secara statistic yaitu kurang dari 0,025 maka pengendalian kualitas CV Anugrah Jaya dikatakan baik

Berdasarkan hasil analisa menggunakan perhitungan diagram control cacat C 10 persen inspection diperoleh besar nilai CL atau besar ratarata kerusakan produk adalah 1,910 persen atau 0,019 sedangkan besar UCL atau batas kendali dari produk sebesar 2,53 persen atau 0,0253 dan besar LCL atau batas standart secara statistic adalah 1,29 persen atau 0,0129 .

Tabel 3. Hasil Diagram Control CacatC 10 Persen

\begin{tabular}{lllll}
\hline Bulan & $\begin{array}{c}\mathrm{P} \\
\text { misdruk }\end{array}$ & $\mathrm{CL}$ & $\mathrm{UCL}$ & $\mathrm{LCL}$ \\
\hline Mei & $1,94 \%$ & 0,019 & 0,0253 & 0,0129 \\
Juni & $1,91 \%$ & 0,019 & 0,0253 & 0,0129 \\
Juli & $1,95 \%$ & 0,019 & 0,0253 & 0,0129 \\
Agustus & $1,92 \%$ & 0,019 & 0,0253 & 0,0129 \\
September & $2,09 \%$ & 0,019 & 0,0253 & 0,0129 \\
Oktober & $1,98 \%$ & 0,019 & 0,0253 & 0,0129 \\
november & $1,63 \%$ & 0,019 & 0,0253 & 0,0129
\end{tabular}

Dengan menggunakan diagram control cacat C 10 persen inspection Pada bulan Mei 2017 besar persentase kerusakan produk adalah 1,94 persen atau 0,0194 berada di bawah batas toleransi misdruk secara statistic yaitu kurang dari 0,0253 maka pengendalian kualitas CV Anugrah Jaya dikatakan baik

Pada bulan Juni 2017 besar persentase kerusakan produk adalah 1,91 persen atau 0,0191 berada di bawah batas toleransi misdruk secara statistic yaitu kurang dari 0,0253 maka pengendalian kualitas CV Anugrah Jaya dikatakan baik

Pada bulan juli 2017 besar persentase kerusakan produk adalah 1,95 persen atau 0,01945 berada di bawah batas toleransi misdruk secara statistic yaitu kurang dari 0,0253 maka pengendalian kualitas CV Anugrah Jaya dikatakan baik

Pada bulan agustus 2017 besar persentase kerusakan produk adalah 1,92 persen atau 0,0192 berada di bawah batas toleransi misdruk secara statistic yaitu kurang dari 0,0253 maka pengendalian kualitas CV Anugrah Jaya dikatakan baik

Pada bulan september 2017 besar persentase kerusakan produk adalah 2,09 persen atau 0,0209 berada di bawah batas toleransi misdruk secara statistic yaitu kurang dari 0,0253 maka 
pengendalian kualitas CV Anugrah Jaya dikatakan baik

Pada bulan oktober 2017 besar persentase kerusakan produk adalah 1,98 persen atau 0,0198 berada di bawah batas toleransi misdruk secara statistic yaitu kurang dari 0,0253 maka pengendalian kualitas CV Anugrah Jaya dikatakan baik

Pada bulan November 2017 besar persentase kerusakan produk adalah 1,63 persen atau 0,0163 berada di bawah batas toleransi misdruk secara statistic yaitu kurang dari 0,0253 maka pengendalian kualitas CV Anugrah Jaya dikatakan baik

Berdasarkan uraian pertanyaan yang sudah dilakukan untuk mengidentifikasi permasalahn yangv terkait dengan penyebab ketidaksesuain kualitas hasil produksi dapat digolongka sebagai berikut yaitu (a) factor man (manusia) para pekerja yang terlibat dalam kegiatan produksi, (b) lingkungan yaitu suasana yang tercipta dalam lingkungan perusahaan khususnya bagian produksi, (c) mesin yaitu mesinmesin dan berbagai perlatan yang digunakan dalam proses produksi (d) metode atau perintah kerja yang harus diikuti dalam proses produksi
Berdasarkan diagram sebab akibat factor factor yang menyebabkan ketidaksesuain kualitas hasil produksi yang disebabkan oleh manusia adalah factor kesalahn seting poin yang diakibatkan dari keinginan pekerja yang ingin cepat menyelesaikan pekerjaannya, kedua yaitu kesalahn proporsi komposisi penyusunan bahan baku yang kurang sesuai dengan takaran atau ukuran, dalam hal ini pemicunya adalah karena pekerja kurang memperhatikan intruksi kerja . factor berikutnya adalah factor mesin, mesin rusak karena kurang perawatan dan kurang pengawasan dari pekerja sehingga mesin kurang bekrja maksimal, factor selanjutnya adalah factor lingkungan karena kondisi gudang penyimapanan bahan baku untuk pembuatan roti kurang optimal sehingga menyebabkan bahan baku menjadi kotor atau rusak karena tercampur dengan debu dan kotoran.

Setelah mengetahui factor-faktor yang menyebabkan ketidaksesuain kualitas hasil produksi maka dibuatlah usulan dengan metode kaizen. (a)Untuk factor manusia, direkomendasikan untuk mengawasi kinerja pegaawai dan membuat instruksi kerja yang jelas, melakukan evaluasi secara berkala dan melakukan pengawasan secara langsung, 
(b) untuk factor mesin perlu dilakukan pengawasan secara berkala agar perawatan mesin tetap terjaga , membersihkan mesin. (c)Untuk factor lingkungan perlu dilakukan perubahan yaitu terus mengawasi gudang agar gudang tetap tertutup dan membersihkan gudang setiap waktu agar kotoran dan debu tidak dapat masuk sehingga bahan baku tetap terjaga kualitasnya. Untuk factor metode (d) perlu dilakukan intruksi yang jelas kepada pegawai agar bahan baku yang dicampurka atau digunakan sesuai denga porsi dan ukuran.

\section{PENUTUP}

\subsection{Simpulan}

Berdasarkan hasil penelitian yang telah dilakukan dapat di tarik kesimpulan sebagai berikut: (1) bahwa pendekatan Total quality control dapat meminimalisasi resiko kerusakan produk pada CV Anugrah Jaya dengan hasil CL 0,019, UCL sebesar 0,025 dan LCL sebesar 0,013 dari hasil menunjukkan bahwa bahwa prosentase misdruk berada di bawah garis UCL yaitu kurang dari 0,025 yang menunjukkan jika Total quality control atau pengendalian kualitas produk dari CV Anugrah Jaya dikatakan baik, sedangkan dengan menggunkan diagram control cacat 100 persen menunjukkan CL 1,910 persen , UCL sebesar 2,53 persen dan LCL sebesar 1,29 persen yang menunjukkan bahwa prosentase misdruk berada di bawah garis UCL yaitu 0,0253 yang menunjukkan jika Total quality control atau pengendalian kualitas produk dari CV Anugrah Jaya dikatakan baik (2) factor factor penyebab kegagalan kualitas produk disebabkan oleh factor manusia, factor mesin, factor lingkungan dan factor metode.

\subsection{Saran}

Beberapa yang dapat disarankan adalah : (1) Total quality control dapat digunakan oleh perusahaan untuk meminimalisasi resiko kerusakan produk sehingga dapat memberikan keuntungan yang maksimal dan menekan biaya agar tidak mencapai biaya yang tinggi, (2) dengan mengetahui faktor-faktor penyebab kegagalan kualitas produk dapat membantu perusahaan untuk meningkatkan pengawasan pada iemitem yang menyebabkan kerussakan produk cacat

\section{DAFTAR PUSTAKA}

Haming Murdifin. 2014. Manajemen Produksi modern. Bumi Aksara 
Hasanuddin, 2014. Analisis Total Quality Control (TQC) Dalam Usaha Menekan Tingkat Kecacatan Produk pada UD. Madani Putra Indah Solokuro Lamongan. Lamongan : Universitas Islam Lamongan.

Mahmudah, Heny. 2013. Analisa Pengaruh Sistem Manajemen TQC Terhadap Tingkat Kerusakan Produk (Studi Kasus Pada Pt. Sinar Kayu Abadi). Jurnal Tesis Manajemen. Surabaya.

Malayu, 2016. Manajemen Sumber Daya Manusia, Jakarta : PT. Bumi Aksara.

Martiningsih, Indah, 2015. Analisis Total Quality Control (TQC) Dalam Usaha Memperkecil Tingkat Kecacatan Produk Air Minum dalam Kemasan pada CV. Aidrat Pondok Pesantren Sunan Drajat Banjaranyar Paciran Lamongan. Lamongan : Universitas Islam Lamongan.

Mustofa, Habib, 2016. Analisis Total Quality Control (TQC) Dalam Usaha Memperkecil Tingkat Kecacatan Produk pada CV. Aidrat Pondok Pesantren Sunan Drajat Banjarwati Paciran Lamongan.
Lamongan : Universitas Islam Lamongan.

Sugiyono 2014. Metode Penelitian Kuantitatif Kualitatif Dan R\&D. Bandung : Alfabeta.

Suwarto. 2013. Penerapan Konsep Pengendalian Mutu Terpadu dan Gugus Kendali Mutu Sebagai Usaha Memenuhi Kepuasan Karyawan Kepuasan Organisasi dan Kepuasan Pelanggan. Jurnal Tesis Manajemen. Jakarta 